\title{
The Tshwane Homeless Summit as dramaturgy: a contextual, trans- disciplinary epistemology from below
}

Wayne Renkin ${ }^{1, *}$ Stephan de Beer ${ }^{2}$

${ }^{1}$ Research Associate at the Centre for Contextual Ministry, University of Pretoria;

Project Coordinator, Tshwane Leadership Foundation; e-mail: wayne.renkin@up.ac.za

${ }^{2}$ Director, Centre for Contextual Ministry; Senior Lecturer, Department of Practical

Theology, University of Pretoria, e-mail: stephan.debeer@up.ac.za

${ }^{*}$ Corresponding Author

Centre for Contextual Ministry, Faculty of Theolog

University of Pretoria, Private Bag X20,

Pretoria 0028

South Africa

Work telephone:+27 (12) 420-4951/2

Cell phone number:+27 844446132 (Renkin) 


\section{Abstract}

In this article we propose a contextual, trans-disciplinary epistemology from below, as explored through the lenses of the Tshwane Homeless Summit and the broader policy-making process of which it formed a part. It considers the Tshwane Homeless Summit as dramaturgy, wondering whether the stage that was set was predetermined or allowed for dissensus, irruption and surprise. The reflection of this article departs from a contextual theological perspective, suggesting that a contextual, trans-disciplinary epistemology from below requires a contextual spirituality in which the homeless/God will take centre stage.

\section{Keywords:}

dramaturgy; contextual, trans-disciplinary epistemology; homelessness; from below

\section{Introduction}

Ivone Gebara (1999:21) emphasized the close relationship between hierarchical power structures in society, and how we generate knowledge. It is essential to revisit our ways of generating knowledge, indeed of knowing itself, in the light of these hierarchical power structures.

'Working on epistemology is not just a matter of trying to influence the process of transmitting knowledge; it is working toward changing the hierarchical power structure itself, which continues to propagate itself in the underlying structures of our society and, in consequence, of our knowing.'

In this article we are reflecting on epistemology through the lenses of a recent (and ongoing) process in the City of Tshwane to share and generate knowledge regarding homelessness, in order to inform the city's policy and strategy on homelessness. At the heart of this rather comprehensive process was the Tshwane Homeless Summit, which took place on 25-26 May 2015. 
We are considering the Summit as dramaturgy, taking central stage as part of a more comprehensive trans-disciplinary research process. We are searching for, and proposing, a contextual, trans-disciplinary epistemology from below.

This article will consider in how far the Summit represented such an epistemological shift, expressing an approach that is indeed more contextual, trans-disciplinary and from below. Was the Summit as dramaturgy only 'playing' such knowledge production 'from below', or was it indeed embodying transforming knowledge in the way in which it both transformed what and how we know with regard to homelessness, but also in the way in which participants in the Summit were potentially transformed through the ways in which knowledge - and life experiences - were shared?

\section{A contextual spirituality from below: the homeless/God at the centre}

We are offering these reflections as part of a trans-disciplinary engagement, although our own point of departure is to do theology in a contextual or liberationist way.

Contextual theologies are insistent on doing theology from below, on the margins, through the eyes of those who are often silence and violated. "From below" refers to contextual theology's intentional location in solidarity with those who are particularly poor, vulnerable or socially excluded, deliberately inviting their voices, knowledges or experiences in shared processes of knowledge generation. ${ }^{1}$

As activist scholars we engage in this process of policy-making convinced that the concerns of homeless people should be made a central priority by local government, faith communities, the academy and civil society at large, if we are to build a good city.

Our own commitments are guided and sustained by a contextual spirituality seeking the common good and being urgent about removing any obstacle that prevents marginal, voiceless and homeless people from participating at a table where they too can experience goodness, mercy and justice.

\footnotetext{
${ }^{1}$ See Cochrane's article Christ from Above, Jesus from Below (1994) for a more in-depth analysis, also Paul Farmer's article On Suffering and Structural Violence: A View from Below (1996)
} 
The contextual spirituality that guides our own contextual engagement with homelessness is life- and dignity-affirming, rooted in grace and hospitality, inclusive, in solidarity with the poor, unifying and reconciling, justice-seeking, transformational, focusing on personal, social and systemic transformation, concerned with all of life, and discerning the presence of God in people's daily struggles (Banda, 2009; de Villiers, 2008; Kritzinger, 2014, 2010).

It is a 'spirituality of the poor' that 'enables the poor and the oppressed to struggle for liberation' (Cochrane et al., 1991:79, 80), in partnership with the God of the poor. It is at the same time a 'spirituality of empowerment and hope', opposing injustice and death in our society, keeping alive 'hope against hope', until Christ comes (Cochrane et al., 1991:80-83).

A contextual, trans-disciplinary epistemology from below, therefore, will seek to create hospitable spaces for sharing that is dignified, equal, life-affirming, liberating and justiceseeking. In theological terms it would be spaces in which God will be discerned among the poor; in which knowledge will be constructed in circles of love; in which actions will be discerned that could overcome death-dealing conditions

Our reflections in this article are therefore by no means neutral, but seek to be both descriptive and critically reflective on what we perceived to be an innovative process of knowledge generation and policymaking in our city, focusing on street homelessness.

\section{Towards a contextual, trans-disciplinary epistemology from below}

Traditional epistemologies seek for universal truths and to be universally applicable, are embedded in hierarchical power structures that favour the knowledge of some over the knowledge of others. It is often, as Eflin (2008:46) describes it, a "view from nowhere". It regards the particularities of local contexts ('socially, historically and economically') and specific constructs (historical, cultural, racial, gender, spatial, economic, or other constructs) irrelevant. It strips away all the particularities to the point that it remains only with abstract, a-contextual "knowledge", which, one can argue, is not honest knowledge at all any longer (cf. De Beer, 2014a; Eflin, 2008; Foth et al., 2007). 
Traditional protestant theology seeks to create universally applicable doctrinal principles and bases itself on so-called eternal truths' (Gebara, 1999:39, 40). These eternal truths are unquestionable and 'always were so and always will be so.' Knowledge rests on these eternal truths without much space to generate or produce new and indeed, contextually appropriate knowledge. Its starting point is 'the exposition of Scripture and distilling universal principles of doctrine and ethics out of it, before applying those to a particular context' (Kritzinger, 2008:767).

Authoritative knowledge is typically subscribed to white, male and professional. Anyone outside these categories is not regarded as people with equal forms of knowledge. They are not invited or valued in processes of knowledge generation or knowledge production, and, therefore, we argue that society is much poorer for it. The custodians of knowledge and truth in theology and the church have always been white men. Even though white men are by no means representative of global society, it was always possible for a 'person of privilege to develop a vision of the structure of epistemic domination and subordination' (Eflin, 2008:53). Cochrane, De Gruchy and Peterson (1991:30) describe the ways in which power determines "knowing" in local communities rather aptly:

'We are used to having our perspectives on what is needed in a community determined by those who normally wield the most influence - the trained professionals, the leading business people, the officially sanctioned politicians and their organs of communication, the religious authorities, and so on. Their actual, objective power (in terms of finance, law, media, bureaucracies, committee positions, contacts, etc.) is enhanced by the ideological power which they wield in determining the local community's view of itself. But the way in which these two forms of power are wielded may often be to further the interests of the influential themselves, even if they see themselves as 'rightly' those who should decide what is in the best interests of others'

In addition, traditional epistemologies are mostly embedded in hierarchical power structures. We can think of it as hierarchies of knowledge. Gebara (1999:25) makes this close link between knowledge and power: 
'The poor and women were always associated with the lowest level of abstraction - of knowledge, of science, and of wisdom. The hierarchizing of knowledge runs parallel to the hierarchizing of society itself that is characteristic of the patriarchal world.'

In response to such traditional epistemologies, our methodological approach is to retrieve voices that argue for contextual, trans-disciplinary epistemologies from below. We acknowledge that the retrieval and articulation of people's lived experiences are legitimate forms of epistemology. Furthermore, it should contribute how we 'know' or 'understand' society. Eflin emphasized the importance 'to broaden our view of what constitutes legitimate ways to create knowledge and vouch for its justifiability' (Foth et al., 2007:3, 4).

In doing theology contextually, alternative epistemologies are always at work. Contextual theologies firstly value people's lived experiences (Gebara, 1999:61). Secondly, doing theology contextually is about deep immersion in and critical analysis and deconstruction of real-world situations and challenges. And thirdly, doing theology contextually is about seeking for liberating and transformational responses to real-life challenges, in collaboration with those who deeply suffer, often as a result of being excluded or violated by hierarchical power structures

A trans-disciplinary approach to research and knowledge generation fits well with the core tenets of contextual theologies. Klein, et al (2012:7) describes trans-disciplinarity rather comprehensively as such:

'Transdisciplinary research starts from tangible, real-world problems. Solutions are devised in collaboration with multiple stakeholders. A practice-oriented approach, transdisciplinarity is not confined to a closed circle of scientific experts, professional journals and academic departments where knowledge is produced. Ideally, everyone who has something to say about a particular problem and is willing to participate can play a role. Through mutual learning, the knowledge of all participants is enhanced, including local knowledge, scientific knowledge, and the knowledge of concerned industries, businesses, and non-governmental organizations (NGO's). The sum of this knowledge will 
be greater than the knowledge of any single partner. In the process, the bias of each perspective will also be minimized'

\section{Dramaturgy: a way of understanding knowledge generation and policy- making}

One way of understanding the process of knowledge generation for policy-making, in this article reflected in a Homeless Summit, is as dramaturgy. Hajer (2005) speaks of the 'dramaturgy' 'of the policy deliberation process' (cf. Swilling, 2012:2).

A dramatic production sets out to achieve a certain outcome through a staged production. Orchestrating of a dramatic production includes a script and a physical setting where the production is staged; this ensures a certain outcome. The production has a pattern of performances which dictates who can perform and when they can perform. All of these elements are crucially important to achieve the set outcome. In traditional policy-making processes 'staged performances' are created where the outcomes were predetermined. There is a policy-maker or 'production manager' who is 'mandated to organise the process'. The processes are then set up in a certain way that will ensure 'consensus and suppress conflict and the so-called "difficult questions"': (Hajer, 2005:630; Swilling, 2012:2). The organiser has a script and determines the physical setting (venue). A production has a series of 'performances' and predetermined rules about who can participate in the performance and when, which obviously shape the outcome of the production. These 'performances' are chaired or choreographed 'in a certain way' and 'in a certain language' to only allow certain voices that are deemed as being experts of knowledgeable and that will also ensure a consensual outcome, this process tends to be exclusive. The 'script', 'performances', and 'venue' all contribute to ensure a consensual process and outcome (Hajer, 2005:624; Swilling, 2012:2).

Hajer (2005:624) notes how 'even with the same cast policy deliberation can change face through experiments with new settings and stagings' and that in the policy deliberation process', the "formalistic participatory processes are often meaningless because stakeholders simply play out predetermined roles as defined by the script, setting and stage managing" (Swilling, 2012:2). Therefore a participatory policy-making 
process is required to ensure the outcomes are not 'predetermined' and that all knowledge is surfaced. This can be ensured by recognising more intentionally the 'performative dimention of policy deliberation' and rethinking the physical setting (venue) to ensure optimum and free participation (Hajer, 2005:641, 624). The Tshwane Homeless Summit made use of the World Café, as one of its methods, precisely to give expression to performative, interactive and embodied aspects of knowledge-generation and policy-making.

\section{Pathways out of homelessness: a trans-disciplinary research project using a mixed-method approach}

The complexity of homelessness was emphasized in the HSRC-led research on homelessness, published in 2010 in Development Southern Africa (cf. Cross and Seager, 2010). A basic assumption, and eventually also conclusion, of the more recent project, Pathways out of Homelessness, was that the complexity of homelessness requires a policy and strategy that will be integrated, holistic, inter-sectoral and interdepartmental in its approach.

Homelessness in South Africa, and elsewhere, cannot be treated through a 'one-size fits all' approach and solutions to homelessness cannot be reduced to only social, economic or housing interventions, but require all of that and more. Overcoming homelessness cannot be the sole responsibility of public sector, particularly local government, but finding solutions need to be owned by all sectors in the city: government, private sector, the third sector ('community based, faith-based and nonprofit organisations (NPOs), local citizens or citizens' groups) and the academy (cf. Cross \& Seagar, 2010; De Beer, 2014c:120). Engagement with street homelessness should not only be the responsibility of local government, but provincial and national government also need to consider policy, strategy and budgetary implications if the increase in long-term homelessness is going to be reversed (Cross \& Seagar 2010). In order to address the complexities of homelessness, the different types of knowledge in the city need to be retrieved, shared, documented and integrated into possible solutions contained in policy and strategy. We recognized that these different types of knowledge were often not documented and therefore lost to important policy-making 
processes. It is with this in mind that the Summit was deliberately created to be a space where very diverse voices could all be heard, in order to discern possible pathways out of homelessness, and then construct policy and strategy together, in ways that can point to possibly viable long-term solutions.

It recognized latent knowledge in community-based organizations that have developed alternatives to homelessness for many years. It recognized the 'expertise' that is with homeless and former homeless individuals who had to navigate life on the streets, develop resilience in the face of all the odds, and tenacity in finding (and sustaining) pathways out of homelessness. It recognized that city officials and politicians had their own knowledge and experiences to draw from, both in terms of what potentially works, but also where policy processes in the past have failed us.

More than 40 academics from the University of Pretoria and University of South Africa, coming from 9 different disciplines, engaged in research conducted in preparation for the Summit.

In the first stage of the research project a conceptual and methodological framework was developed for the project. A mixed-method approach was followed in conducting the actual research, including "literature studies, critical policy analysis, focus groups, ethnographic interviews, unstructured interviews, case studies, critical spatial analysis, contextual Bible studies, open source technology and geographical mapping" (de Beer and Vally, 2015:13).

76 interviews were conducted with practitioners from 19 different organisations or projects, specifically in Region 3 of the City of Tshwane. The purpose was to document existing practices addressing street homelessness, retrieving possible clues for policy and strategy development. Narratives of homeless and former homeless people were documented through conversations and contextual Bible studies in which 100 homeless people told their stories, with a view both of uncovering the complexities of street homelessness as well as discerning possible pathways out. Health assessments were done with 150 homeless people through health survey forms. 
A spatial analysis was done mapping both the concentration of homelessness as well as distribution of services, critically reflecting on how spatial location possibly affects impact of services (de Beer and Vally, 2015:11). A series of focus groups was conducted including homeless and former homeless people, community practitioners, business people, policy makers, and academic researchers (De Beer and Vally, 2015:12).

A critical appraisal of the 2013 homelessness policy was developed, and a revised Policy recommended. This was done through a comparative analysis of both related national and local policy documents, as well as "literature documenting policies and strategies on homelessness in the USA, the UK, Canada, Ireland, India, Australia and Chile" (de Beer and Vally, 2015:12).

The above process culminated in the Summit, during which the World Cafe and round table processes were used, in order to gain optimum participation from everyone present.

The Summit itself was

"not only a very engaging and participative space, but was also a research method in itself, allowing for research findings to be shared with participants, and for a conceptual understanding and proposals for strategic interventions to be further developed and deepened. The different methods complemented each other and often represented a method well used by one discipline or another" (De Beer and Vally, 2015:13).

\section{The Tshwane Homeless Summit: considering pathways out of homelessness}

On 25 and 26 May 2015 the first Tshwane Homeless Summit was held at the Ditsong National Museum of Cultural History in Pretoria. The theme of the Summit and the broader research process of which it formed a central part was Pathways out of Homelessness. 
Held in the capital city of South Africa, this Summit was a first of its kind in South Africa, and held the potential to inform not only local knowledge, policy and strategy, but also national policy and strategy on homelessness. The Summit was both the culmination of a research process and part of the methodology used.

The Summit was co-hosted by four partners: the Tshwane Homelessness Forum², the City of Tshwane, the University of Pretoria, and the University of South Africa. The co-hosting of the Summit and composition of participants were expressions of trans-disciplinarity, ensuring a process seeing 'different academic disciplines working jointly with practitioners to solve a real-world problem' (Klein et al., 2012).

The Summit brought together almost 500 people, including homeless and former homeless individuals, city officials, politicians, policy-makers, community practitioners, religious leaders, academics and researchers, business people, police and members from the general public. More than half of the participants were homeless or former homeless individuals.

The main objectives of the Summit were outlined in the research and strategy document that guided the whole process (De Beer, 2014:1):

(1) To share and produce new knowledge while discerning pathways out of homelessness; (2) 'To generate a deepened awareness and understanding of the realities, complexities \& challenges of homelessness through presenting case studies on homelessness and community-based solutions to homelessness and creating opportunity for homeless and formerly homeless individuals, as well as practitioners dealing with homelessness to share their experiences'; (3) 'To provide input in addressing homelessness through making policy recommendations and proposing strategies for preventing and/or reducing homelessness', and, (4) based on knowledge and data generated, 'to enter into a social contract where different stakeholders accept responsibility for implementing a policy and strategies to address street homelessness in the City of Tshwane'.

\footnotetext{
${ }^{2}$ The Tshwane Homelessness Forum coordinates services and seeks to be a voice for homeless issues. NGOs, FBOs, $\mathrm{CBOs}$, homeless individuals and the city all participate in the Forum.
} 
A key outcome of the Summit was the revision of the 2013 policy on homelessness. Community activists, city officials and the Executive Mayor, all agreed that the 2013 Policy was not sufficient in addressing street homelessness in the City of Tshwane. It did not provide adequate interventions to prevent or end homelessness, it excluded the growing number of foreign nationals being homeless on the city's streets, and it lacked a strategic action plan and a budget that will ensure implementation.

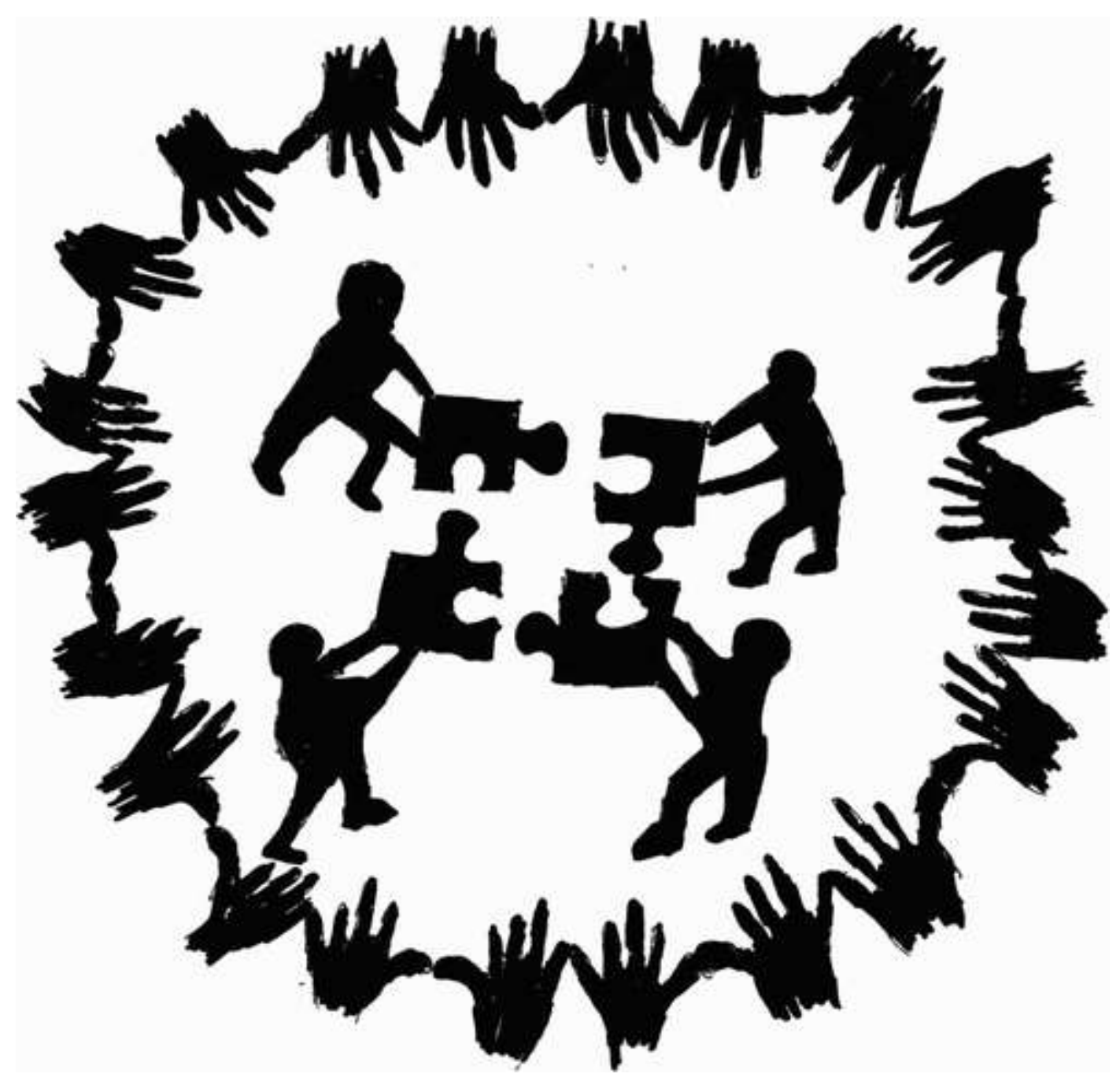

Figure 1. Image drawn by a participant at the Tshwane Homeless Summit illustrating that all parts of society must work together. 
The Summit was constructed to allow diverse voices, including those of homeless and former homeless people, to share experiences and knowledge considered equally valid and appropriate, and to make homelessness visible as a sociopolitical priority and imperative, for various role players in the city to deal with collaboratively. At least in theory, its desire was to practice an epistemology that would subvert traditional hierarchies of knowledge. One of the participants of the Summit, drew a picture (figure 1) as an expression of a transdisciplinary approach and the collaboration of multiple stakeholders, coming together as equal partners.

\subsection{Setting the Stage}

If we understand the Summit as dramaturgy, it is important to understand the nature of the 'performances' that were strung together, as well as of participants that were casted on stage.

\subsubsection{Participants: representing different ways of knowing}

A clear intention of the Summit was for a depth of participation from the homeless community. We cannot speak of homelessness without homeless people present, and without speak together as a community of concern. The "expert knowledge" of homeless people themselves, and of those practitioners who spent years accompanying street homeless people, had to be retrieved in generating not only knowledge but practical wisdom (cf. De Beer, 2014c; Eflin, 2008; Foth et al., 2007:6).

In the process dominant knowledge and discourses about homelessness were deconstructed, through a subversion of knowledge hierarchies and traditional ways of knowledge generation. The absence of homeless people at the table would probably have led to abstract knowledge not informed or refined by existential experiences.

Setting the stage in this way is consistent with both a contextual approach to doing theology and a trans-disciplinary approach to knowledge generation: involving those affected by real-life issues to participate in discovering and drafting real-life solutions. It was therefore important in the planning of the Summit to ensure that at least half of the participants were people who were currently or previously homeless. 
Choosing 'to be sensitive to the needs and voices of the marginalised' (Foth et al., 2007:7), homeless people and their experiences were given centre stage. From a contextual theological perspective, inviting homeless individuals to be centre stage as we consider their precarious conditions in conversation with them is consistent with an understanding of God as biased towards the poor and marginalized.

\subsubsection{Round Tables: wisdom in the circle}

In traditional academic settings, the class room is often set up in a conference style where all participants face in the same direction towards the speaker, who is regarded as the expert, with little or no interaction from the audience ${ }^{3}$.

In preparation for the Summit, it was resolved that this conventional conference style setup would be replaced with an emphasis not on the stage, but on the round tables. The whole space and all participants became the stage, asserting the equality of every person in the room and the invitation to each person to participate and contribute equally.

During the registration process on the first day, it was deliberately ensured that every table had a diversity of participants comprising homeless people, practitioners, politicians, city officials, academics and others. The tables enabled different experiences and ways of knowing to be shared; it facilitated networking opportunities and created spaces for stereotypes to be broken and social barriers to be overcome. An emphasis was placed, throughout the Summit but particularly for the round table interaction, on '(c)ultivating an atmosphere of listening, respect and equality, where all inputs are equally valued and acknowledged' (Koch, 2015:5).

Although this diversity was maintained at almost all 50 tables in the room, there were a few exceptions where there were only homeless people or only politicians. And yet, it was precisely in the diversity that depth of conversation and insight, and innovative foresight occurred.

\footnotetext{
${ }^{3}$ Paulo Freire (2000) uses the idea of a 'culture circle' that allows students and teachers to interact in a different way than the traditional interaction: where the teacher or professor has all the knowledge and answers and the students are only recipients of said knowledge. In the circle the teacher engages the students and the students each other in the process of learning.
} 
'The success of a table's conversation being able to tackle the complexity of the issues was best served where there was diversity of voices and experience at the table' (Koch, 2015:5).

The dramaturgy of the Summit set out to ensure that everyone in the room shared the stage by actively participating in the process and that dissensus, irruption and surprises were allowed. Whether this was completely achieved is a different matter.

The meals formed an integral part of the circle that was created. Participants helped themselves for buffet-style lunches and dinner, after which they joined each other again in circles to share meals at their tables. This allowed for the kind of communion that helped create 'circles of trust' (cf. Palmer, 2004:71-87), however fragile they might have been. Parker Palmer (2004:71-87) speaks of the importance of cultivating such 'circles of trust' as we prepare ourselves for a collective journey towards the common good. In that sense the preparatory work that preceded the Summit, the Summit itself, and the work done to translate resolutions into actions, all present attempts to foster gracious spaces that can be through of as 'circles of trust'.

\subsubsection{Interactive Sessions}

There were a number of plenary sessions in which three forms of inputs were given:

(i) orientation to the event, pledges of commitment from the partners and setting the stage

(ii) presenting research findings as discovered in the process preceding the Summit, therefore almost feeding back the information received from the very audience participating in the Summit

(iii) listening to stories as told by homeless or former homeless individuals and practitioners engaged in the development of innovative solutions to homelessness

The plenary sessions, shared meals and tea times were complemented by interactive sessions which became the heart of the Summit. The interactive sessions provided the opportunity and space for everyone present at the Summit not to only to be part of an 'audience' but to take part as active participants/ actors. Through the facilitation 
process, the facilitator of the sessions challenged participants with key questions and fresh eyed awareness of our own and other's thinking and perception.

The nature of the round tables and interactive sessions enabled conversations between participants around the tables and gave the opportunity for each participant to engage verbally and non-verbally (also through drawing and/or writing) (Koch, 2015:1). It was important to create an atmosphere of listening, respect and equality and it was cultivated through acknowledging everyone around the table's views and inputs as important and valuable.

There were a total of four interactive sessions. Three sessions were guided by key questions and the final session gave each table the opportunity to make a public declaration of their commitment to end homelessness.

Each session was also guided by a specific theme: (1) Visioning alternatives; Engaging possibilities; (2) Creating a showcase/gallery for envisioning alternatives and engaging possibility; (3) Drilling deeper: making the way forward; and (4) Expressing a declaration.

During the Summit, participants were invited to write, draw or doodle on flipchart papers that were used to create a gallery. The gallery was used for further engagement for the presenters and participants.

A few common themes surfaced in the declarations concluding the Summit: collaboration, collective approach, humanity, respect, dignity and Ubuntu. It was also stressed that a truly holistic and integrated approach is a prerequisite for addressing homelessness effectively. The tables that hosted only politicians expressed their commitment for the process, the approval of the proposed policy and finding pathways out of homelessness.

\subsection{Playing on stage: Whose knowledge? Whose power?}

No process is neutral and emptied of all traces of power or hierarchical relationships. Acknowledging the hierarchical power structures and being intentional about subverting these through the kind of stage that is created, is a 
first step towards a different way of knowing. That was the intention of the Summit: to create a stage on which all participants could play. And yet, it is important critical questions about the nature of knowledge and power, even in seeking to set up such an equal and participative stage..

By definition the partners were not equal. The two universities are leading higher education institutions in South Africa and on the continent. Local government hosts the Executive Mayor and political and administrative power in the city. In contrast, the Tshwane Homelessness Forum is representing a range of non-profit organizations, different in size, capacity and influence, as well as individuals still living on the streets. In terms of financial and institutional resources, as well as self-understanding in terms of own agency and possibility, these are not equal partners. And yet, the Summit in its preparation, execution and entering into a social contract, insisted that each partner is equal because of who and what it represented.

There are historical competitions between the two universities and between different non-profit organizations in the Forum. There are historical contestations between individuals who steered the process around specific projects or evictions of homeless people. Homeless individuals prepared to come to the Summit every morning, leaving their space somewhere on the street or in a city park, or next to a river, without the possibility to shower or wash, whilst practitioners, researchers and officials arrived at the Summit from the warmth of their apartments or houses.

Programme directors and presenters represented the different sectors. Homeless voices were heard alongside those of researchers and practitioners. What was going to be said on stage was not rehearsed prior to the "performance". What was shared around the tables was not planned nor predicted.

Although the stage was well created, it was left open for disruption and irruption, as homelessness is not without contestation. Throughout the Summit, there was an underlying tension between wanting to create a consensus outcome for the policymaking process without any contestations, and the chosen methodology of the Summit that invited all voices to be heard. 
In anticipation of the Executive Mayor's arrival, a security sweep was done on the first morning. The programme was delayed with at least thirty minutes, but the Mayor failed to show up. It was apparent that this left a sour taste in the mouths of homeless people and practitioners who believed in the commitment of the Mayor to this process. It was perceived as a sign of disrespect, as being shunned. One of the participant tables raised this as an issue by asking on flipchart paper in big letters: 'Where is the Mayor?'

After an academic raised the issue of the Mayor's absence as well as the absence of homelessness from the City's annual budget, the Mayoral Committee Member tasked to represent the Mayor on the day, left before she could present the Mayor's speech.

Perceptions are valid experiences to be proven wrong through acting out contrary actions. Delaying the entire Summit for the non-arrival of the Mayor was a stark reminder of the hierarchical nature of society, even when the intention of the Summit was to the absolute contrary.

Homeless participants were not quiet or subdued. One of the tables rated a researcher's presentation 4/10 and displayed it in the gallery. Another presenter incorporated the insights and vision of another table in her own presentation on day 2. When a representative from the non-profit sector spoke in a tone that was felt to be condescending by some of the homeless community, he was heckled and challenged on stage. There was continuous interaction between policy-makers, practitioners, homeless persons and presenters. The audience was no longer just an audience, but became participants in this dramaturgy.

The final outcome in the form of a proposed policy and strategy was indeed informed by various processes over many months, as well as diverse inputs at the Summit, articulating the voices of many who had a chance to speak. And yet, some individuals had to finally put together these recommendations. Their biases and preferences in drafting the conclusions cannot be completely denied. It remains an interpretation of what was heard and discerned collectively, translated in the form of a recommended document, that now has to be implemented. 


\subsection{Entering into a social contract}

One of the important outcomes of the Summit was the signing of a social contract between the four partners.

Jean-JacquesRousseau (1762:49) states that, for a social contract to be valid, no person has authority over another and that all legitimate authority must be agreed upon. All parties must benefit, and contribute, equally; such a contract should be between equals and not rulers or ruled, or between powerful and weak.

Already on one important occasion since the Summit and the signing of the social contract did the partners have reason to fall back on the spirit of the social contract, or, to retrieve Rousseau's notion, of the General Will. It helped them to create a difficult but critical conversation around a crisis facing homeless people in the city.

One homeless person declared during the Summit: 'Nothing for us without us', articulating well both the spirit and the nature of this collective process, asking for equal participation and responsibility in seeking the common good.

The social contract departs from a deeper acknowledgment that the reality of homelessness is fundamentally wrong, an expression of economic inequalities and unsustainable disparities, a perversion of the common good (cf. Brueggemann, 2010:1) and therefore require our collective commitment to work for a just alternative.

The social contract is not a legally binding contract, but a moral agreement that homelessness must be eradicated in the City of Tshwane. The signing of the social contract by all four partners makes clear that responsibility to end homelessness does not rest solely on the shoulders of government or civil society, but it is the responsibility of all citizens in the City of Tshwane, individual and corporate, including homeless people themselves, to end homelessness.

By placing homelessness and homeless people at the Centre of the social contract and the Summit, a dramaturgy unfolds that seeks to deconstruct the hierarchical structures of power and knowledge in society. 


\section{The Tshwane Homeless Summit as Dramaturgy: critical reflections}

In planning and choreographing the Tshwane Homeless Summit as dramaturgy, the physical setting and organization of the venue were clearly considered. The Summit was held in a public venue, experienced to be neutral by all participants in the Summit. The programme of the Summit - or the 'performances' - set out to ensure that there were interaction around the tables, at meals, in the gallery space, and in response to the formal presentations. Some 'performances' were done by individuals from the front, but much of the performances' were collectively executed around the tables, and not 'rehearsed' at all.

The participants, or players / actors, were invited in a way that would ensure diverse voices to be heard during the Summit. Freedom was left at the tables and in the gallery for dissenting voices and different imaginaries to be articulated.

The traditional chair of a policy-making process is the policy-maker. As the Summit was a collaborative process between the four partners, the programme, venue and facilitators were decided on together. At times the partners disagreed in meetings and had long and sometimes difficult conversations not just about the possible envisaged outcomes, but about the ethos, space creation and participation during the Summit. All of this was done in the spirit of subverting traditional policy-making processes, and in the interest of participatory policy-making in which those who are supposed to be the primary beneficiaries of the Policy would be central in the crafting of the vision and actions to be taken.

Swilling (2012:2) cautions against 'formalistic participatory processes' in which role players often 'simply play out predetermined roles as defined by the script, setting and stage managing.' It is indeed a question whether the Summit as dramaturgy simply made space for predetermined roles to be played out, even unconsciously, or whether it created sufficient space for disruption, irruption and surprise.

As noted earlier, there were moments during the Summit when there was perhaps a sense that the 'performances' had to be 'managed' better in the interest of consensus. At the same time though, there were clear moments during the Summit when 
dissensus, critique, and diverse and contesting voices, surfaced and were given hospitable space to help inform the collective knowledge we sought to construct together.

It was our perception that the Summit, and the whole process in which it was embedded, moved beyond traditional policy-making processes in terms of the depth and equality of participation. Recommendations made emphasized elements, sometimes controversial, that were previously ignored or excluded from Policy.

At the same time, however, the Summit as dramaturgy could have evoked even more spontaneous participation, and the process and outcomes could have been even deeper, had the whole Summit been choreographed around the methodology of round table conversations. A future Summit might do well to embrace 'open space technology' as format for the whole process, which requires high levels of interaction in circles, from the moment of determining the agenda together during the actual event, to the point of agreeing on outcomes or actions to be taken. Participants gather around a single pressing concern, in this case to find and facilitate pathways out of homelessness, but the themes to be discussed as well as solutions to be developed all occur in the circle / circles (cf. Owen, 2008).

However, it is our sense that the Summit as dramaturgy, in the way in which it took place, was a public and collective ritual that helped to give homelessness visibility, giving voice to voiceless people, creating bonds between different partners, laying the foundation for a social contract, or covenant, upon which collaborative responses can now be developed, hopefully boldly and innovatively so, to mediate pathways out of homelessness.

\section{Conclusion}

Our own understanding of the commitment made by partners is that it is a social covenant that binds people together in terms of certain moral convictions, and therefore goes beyond and deeper than legal obligation. Sustaining the spirit of the social contract, or covenant, probably requires a spirituality - here broadly considered as shared moral conviction in solidarity with the poor - since spirituality is, at least in our 
understanding, 'the core of everything' and could possibly make 'a genuine contribution [...] towards the healing of human brokenness in all its forms, personal and public' (Cochrane et al., 1991:83).

The authors were part of the research process and planning of the Summit and therefore the article was also an attempt to reflect critically on our own engagement, understanding and perception of the process. We consider the Tshwane Homeless Summit as dramaturgy, and the much broader process in which it was embedded, as a small interruption in the city's life.

In how far it will contribute to the liberation of people who are homeless, and a transformation of the minds of officials, politicians and the general public, only time will tell. Such transformations will become visible where the small dramaturgy of the Summit spills over onto the streets and into policy-making and institutional life, asserting the centrality of the homeless/God as a socio-political priority for building a good city.

\section{References}

Banda, Z.J., 2009. "Solidarity with victims": An appraisal of JNJ ( Klippies ) Kritzinger's contribution to the praxis of Liberation Theology. Missionalia 37, 111-124.

Brueggemann, W., 2010. Journey To The Common Good. Westminster John Know Press, Louisville.

Cochrane, J.R., 1994. Christ from Above, Jesus from Below. J. Theol. South. Afr. 88, 314.

Cochrane, J.R., De Gruchy, J.W., Petersen, R., 1991. In Word and Deed: Towards a Practical Theology for Social Transformation. Cluster Publications, Pietermaritzburg.

Cross, C., Seager, J.R., 2010. Editorial. Dev. South. Afr. 27, 1-2. doi:10.1080/03768350903519275

De Beer, S., 2014a. Pathways out of homelessness in the City of Tshwane: Research and Strategy Development for the Homeless Summit 2015. Unpublished, Centre for Contextual Ministry, University of Pretoria, Pretoria.

De Beer, S., 2014b. Reimagining the Third Sector and its Engagement with Higher Education Institutions and Local Neighbourhoods: From Scarcity to Sustainability, 
in: Erasmus, M., Albertyn, R. (Eds.), Knowledge as Enablement: Engagement between Higher Education and the Third Sector in South Africa. AFRICAN SUN MeDI, pp. 119-141.

De Beer, S., 2014c. Whose knowledges shape our city? Advancing a community-based urban praxis. Jure 47, 218-230.

de Beer, S., Vally, R. (Eds.), 2015. Pathways out of Homelessness: Research Report 2015. University of Pretoria, Pretoria.

de Villiers, E., 2008. The interdependence of public witness and institutional unity in the Dutch Reformed family of churches. Verbum Eccles. 728-743.

Eflin, J., 2008. Women and cognitive authority in the knowledge economy, in: Hearn, G., Rooney, D. (Eds.), Knowledge Policy: Challenges for the 21st Century. Edward Elgar Publishing Limited, Cheltenham, Northhampton, pp. 45-58.

Farmer, P., 1996. On Suffering and Structural Violence: A View from Below. Daedalus 125, 261-283. doi:10.1353/rac.0.0025

Foth, M., Odendaal, N., Hearn, G.N., 2007. The View from Everywhere: Towards an Epistemology for Urbanites, in: Remenyi, D. (Ed.), Proceedings of the 4th International Conference on Intellectual Capital, Knowledge Management and Organizational Learning (ICICKM). Academic Conferences Limited, pp. 127-133.

Freire, P., 2000. Pedagogy of the Oppressed, 30th ed. Continuum Publishing Group Inc, New York, London.

Gebara, I., 1999. Longing for Running Water: Ecofemism and Liberation. Fortress Press, Minneapolis.

Hajer, M., 2005. Setting the Stage: A Dramaturgy of Policy Deliberation. Adm. Soc. 36, 624-647. doi:10.1177/0095399704270586

Klein, J.T., Grossenbacher-Mansuy, W., Häberli, R., Bill, A., Scholz, R.W., Welti, M. (Eds.), 2012. Transdisciplinarity: joint problem solving among science, technology, and society: an effective way for managing complexity. Birkhäuser, Basil, Boston, Berlin.

Koch, D., 2015. Facilitation and Co-ordination of the Interactive sessions Tshwane Homeless Summit 25-26 May 2015. Pretoria.

Kritzinger, J.N.J., 2014. Concrete spirituality. HTS Teol. Stud. / Theol. Stud. 70, 1-12. 
doi:10.4102/hts.v70i3.2782

Kritzinger, J.N.J., 2010. Ministerial formation praxis in the Uniting Reformed Church in Southern Africa: In search of inclusion and authenticity. Missionalia 38, 211-234.

Kritzinger, J.N.J., 2008. Faith to faith - Missiology as encounterology. Verbum Eccles. 29, 764-790.

Owen, H., 2008. Open Space Technology: A User's Guide (3rd ed). Berrett-Koehler, Oakland, CA.

Palmer, P.J., 2004. A Hidden Wholeness. The Journey Toward an Undivided Life. Jossey-Bass, San Francisco.

Rousseau, J.-J., 1762. The Social Contract, Theology.

Swilling, M., 2012. Rethinking the Science-Policy Interface in South Africa: Experiments in Co-Production of Knowledge at Different Scales, in: Berlin Conference on the Human Dimensions of Global Environmental Change. Berlin. 